\title{
Systematic Review \\ Stem Cell Therapies for Cerebral Palsy and Autism Spectrum Disorder-A Systematic Review
}

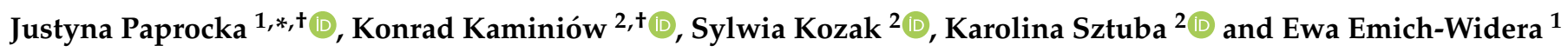 \\ 1 Department of Pediatric Neurology, Faculty of Medical Sciences in Katowice, Medical University of Silesia, \\ 40-752 Katowice, Poland; marekwidera@wp.pl \\ 2 Students' Scientific Society, Department of Pediatric Neurology, Faculty of Medical Sciences in Katowice, \\ Medical University of Silesia, 40-752 Katowice, Poland; kaminiow.k@gmail.com (K.K.); \\ sylwiakozak@icloud.com (S.K.); k.sztuba96@gmail.com (K.S.) \\ * Correspondence: justyna.paprocka@interia.pl \\ + These authors contributed equally to this work.
}

check for updates

Citation: Paprocka, J.; Kaminiów, K.; Kozak, S.; Sztuba, K.; Emich-Widera, E. Stem Cell Therapies for Cerebral Palsy and Autism Spectrum Disorder-A Systematic Review. Brain Sci. 2021, 11, 1606. https:// doi.org/10.3390/brainsci11121606

Academic Editor: Alfredo Bellon

Received: 18 October 2021

Accepted: 1 December 2021

Published: 3 December 2021

Publisher's Note: MDPI stays neutral with regard to jurisdictional claims in published maps and institutional affiliations.

Copyright: (c) 2021 by the authors. Licensee MDPI, Basel, Switzerland. This article is an open access article distributed under the terms and conditions of the Creative Commons Attribution (CC BY) license (https:// creativecommons.org/licenses/by/ $4.0 /)$.

\begin{abstract}
Autism spectrum disorder (ASD) and cerebral palsy (CP) are some of the most common neurodevelopmental diseases. They have multifactorial origin, which means that each case may manifest differently from the others. In patients with ASD, symptoms associated with deficits in social communication and characteristic, repetitive types of behaviors or interests are predominant, while in patients with $\mathrm{CP}$, motor disability is diagnosed with accompanying cognitive impairment of various degrees. In order to minimize their adverse effects, it is necessary to promptly diagnose and incorporate appropriate management, which can significantly improve patient quality of life. One of the therapeutic possibilities is stem cell therapy, already known from other branches of medicine, with high hopes for safe and effective treatment of these diseases. Undoubtedly, in the future we will have to face the challenges that will arise due to the still existing gaps in knowledge and the heterogeneity of this group of patients. The purpose of this systematic review is to summarize briefly the latest achievements and advances in stem cell therapy for ASD and CP.
\end{abstract}

Keywords: stem cell therapy; cerebral palsy; autism spectrum disorder

\section{Introduction}

With the continuous development of medicine, humankind is gaining new possibilities to treat conditions that until recently could only be treated symptomatically. Autism spectrum disorders and cerebral palsy are among such disorders, which are still a mystery to doctors and scientists. According to ICD-10 (International Classification of Diseases, 10th revision) and DSM-5 (Diagnostic and Statistical Manual of Mental Disorders, 5th edition), autism spectrum disorder is defined as a communication/social interaction disorder with associated repetitive behaviors [1,2]. ASD includes various neurodevelopmental disorders with diverse etiologies such as Autistic Disorder, Pervasive Developmental Disorder not Otherwise Specified (PDD-NOS), and Asperger's Disorder. The overall estimated prevalence of ASD ranges from $1.5 \%$ to $1.8 \%$ and an increase has been reported around the world over the past decade [3,4]. Males show a prevalence of $2.8 \%$ and females a prevalence of $0.65 \%$, making the male-to-female ratio of 4.3:1 [3,4]. A combination of genetic, environmental and immunological factors underlie ASD [5-12]. It is estimated that up to 1000 potential genes are involved in the genetic determinants of ASD, which are linked by multiple (familial) patterns of inheritance [5-9]. Most of them are responsible for the most essential processes in brain organization and function, such as synaptogenesis, neurotransmitter metabolism, broadly defined neurometabolic, or proper mitochondrial function [13-18]. There is also known evidence for alterations in GABAergic circuits in ASD; this evidence comes from postmortem studies showing significantly reduced GAD65/GAD67 levels (two isoforms of glutamic acid decarboxylase which synthesizes the inhibitory neurotransmitter y-aminobutyric acid, GABA) in the parietal cortex and cerebellum and alterations 
in $\mathrm{GABA}_{A}$ and $\mathrm{GABA}_{B}$ receptors in postmortem brains of autistic subjects [13-18]. These alterations may be the result of widespread changes in GABA innervation and/or release, which may lower the threshold for developing seizures, given the high co-morbidity of ASD and epilepsy [13-18]. Moreover, among ASD patients, due to changes in the glutamatergic circuit, there is an increase in excitatory synapse number and spine density. Together, these findings suggest that heterogeneous alterations in glutamatergic and GABAergic systems in the ASD brain may coincide with an overall increased arousal/inhibition ratio, which may manifest as epileptic symptoms, macroscopic brain volume changes, and behavioral changes [13-18]. In reference to the close relationship between the immune and nervous systems in the early period of brain development, a hypothesis was developed concerning the origin of disorders in ASD. It assumes a link between neuroinflammation, microglial activation, and/or immune dysregulation in patients with ASD [11,19-22]. Many risk factors for autism spectrum disorders are known, mainly related to maternal exposure before and during pregnancy. These include exposure to chemicals (e.g., toluene, pesticides), exposure to heavy metals (arsenate, mercury, lead), perinatal trauma, infections during pregnancy, hypoxia, and preterm delivery $[10,12,23,24]$. In addition to the core symptoms, which restrict range of activities and impairments in social communication, patients with ASD also suffer from concentration disorders, sleep disorders, hyperactivity, motor disorders (e.g., clumsiness or hypotonia), or disorders of normal functioning of the digestive system (chronic constipation and/or diarrhea) [25-27]. Current treatments for patients with ASD are limited to psychological interventions, occupational therapy, speech therapy, behavioral therapy, and pharmacotherapy $[28,29]$. Currently available medications registered for the treatment of patients with ASD target some comorbid conditions but have not been shown to be effective in alleviating or ameliorating core symptoms such as impaired social interaction and communication $[22,27,30,31]$. In addition, these drugs (e.g., SSRIs, antipsychotics) cause side effects such as extrapyramidal symptoms, sedation, and weight gain [26,32]. All of these significantly reduce the patients' quality of life. Through functional impairment and the resulting dependence on caregivers and facilities, as well as the lack of therapy aimed at treating the causes of the disorder, the exclusion of ASD patients from society continues to progress.

A very similar situation exists with cerebral palsy. It consists in a group of permanent movement and posture disorders caused by anomalies in the developing brain [33-36]. These disorders are most often accompanied by sensory, perceptual, cognitive, visual, hearing problems, epilepsy, and musculoskeletal problems [36-39]. Due to the many problems it generates, cerebral palsy is recognized as one of the most common causes of disability in children $[36,40,41]$. The overall prevalence of $C P$ is about $2-3$ cases per 1000 births, noting that it is significantly higher in children born prematurely (2/1000 births) compared to children born at term (1.1/1000 births) [42-46]. The prevalence rate reaches higher values in developing countries $[44,45,47]$. The etiology is still unknown, but a complex contribution of genetic, prenatal factors (such as hypoxia, intrauterine growth restriction, or infection) and prematurity is suspected [33,48-50]. However, in about $80 \%$ of cases, the cause of onset cannot be determined and is considered idiopathic [33,51]. It is suspected that CP patients develop persistent inflammation of the nervous system and subsequent apoptosis, which usually occurs as a result of hypoxia-induced trauma [52]. The current therapeutic management of $\mathrm{CP}$ patients requires a multidisciplinary approach that takes into account the medical, social, psychological, and educational needs of the patient $[33,36,53]$. Treatment includes the use of neurotrophic drugs, physiotherapy, rehabilitation, surgical procedures (such as neurectomy and rhizotomy) and intramuscular injections of botulinum toxin, and other types of symptomatic treatment tailored to the symptoms reported by the patient or their caregivers $[33,36,53]$. However, despite the many options, the effectiveness of therapies is limited because none of the treatments target brain damage [36,54]. Therefore, new therapeutic options are needed that could repair damaged neural tissues, which would improve patients' quality of life by improving motor function. 
The benefits of therapeutic interventions for individuals with both ASD and CP are limited. In the search for better outcomes in the treatment of these conditions, alternative and complementary therapies are being explored. Due to the involvement of genetic and immunological components in the etiology of these diseases, the need for biological therapy trials targeting the etiology of ASD and CP, especially at the cellular and molecular levels, is indicated. Such opportunities for patients with ASD and CP have been created by the possibility of stem cell therapy. Recent reports suggest that stem cell transplantation results in improvement in several different neurological conditions including stroke, amyotrophic lateral sclerosis, Alzheimer's disease, spinal cord injury, or Parkinson's diseases [55-59]. It seems to be a promising option, especially when applied to the brain, a structure generally characterized by slow and limited regeneration. Using stem cells, based on their excellent regenerative abilities, as well as the possibility of differentiation into specific cell types and immunomodulatory effect, we can significantly accelerate the process of repair and remodeling of damaged, immature neurons forming pathological brain structure in ASD and $\mathrm{CP}$ patients.

This paper presents a summary of the results of the latest research on stem cell therapies in autism spectrum disorder and cerebral palsy. The collected data were divided into sections, representing types and details of stem cell therapy for each of these disorders.

\section{Materials and Methods}

\subsection{Search Strategy}

A systematic search was conducted in the Pubmed, Medline, and Google Scholar databases to identify the literature related to the stem cell therapies in cerebral palsy and autism spectrum disorder. Three authors independently screened the above-mentioned databases. Each database was searched individually, and search terms were applied line by line and were replicated in every source. The following terms were used in the searching process: "stem cell", "stem cell therapy" in combination with terms such as "autism", "autism spectrum disorder", or "cerebral palsy". The entire process of searching relevant papers by three reviewers (period for establishing a database of relevant articles) lasted from February 2021 to June 2021, with numerous subsequent updates basedon the latest scientific reports.

\subsection{Study Selection and Appraisal}

Manuscripts were reviewed for titles, abstracts, and entire texts based on the following criteria. The inclusion criteria were as follows: (1) original papers; (2) reviews; (3) stem cell therapy related to autism spectrum disorder or stem cell therapy related to cerebral palsy as a key topic of the paper. The exclusion criteria were as follows: (1) methodological studies, editorials, commentaries, letters, hypotheses; (2) no available abstract; (3) manuscripts in a language other than English. Titles, abstracts, and full-text articles were screened against the inclusion criteria by three reviewers. Next, manual search and reference and citation tracking were undertaken by three reviewers (K.K., S.K., and K.S.) who established the final selection of papers. Any disagreement was resolved by discussion. In the case of no agreement, fourth and fifth independent reviewers made the final decision.

\subsection{Development of the Review}

The analysis was conducted in the following steps. The first step was related to the analysis of selected papers based on titles and abstracts, the second step was connected with the analysis of full-text papers, and the last step included the analysis of the collected data.

\section{Results}

The preliminary search of the database showed 1037 studies, of which 364 were verified based on the entire manuscript. A total of 171 studies were finally included in the analysis (Figure 1). 


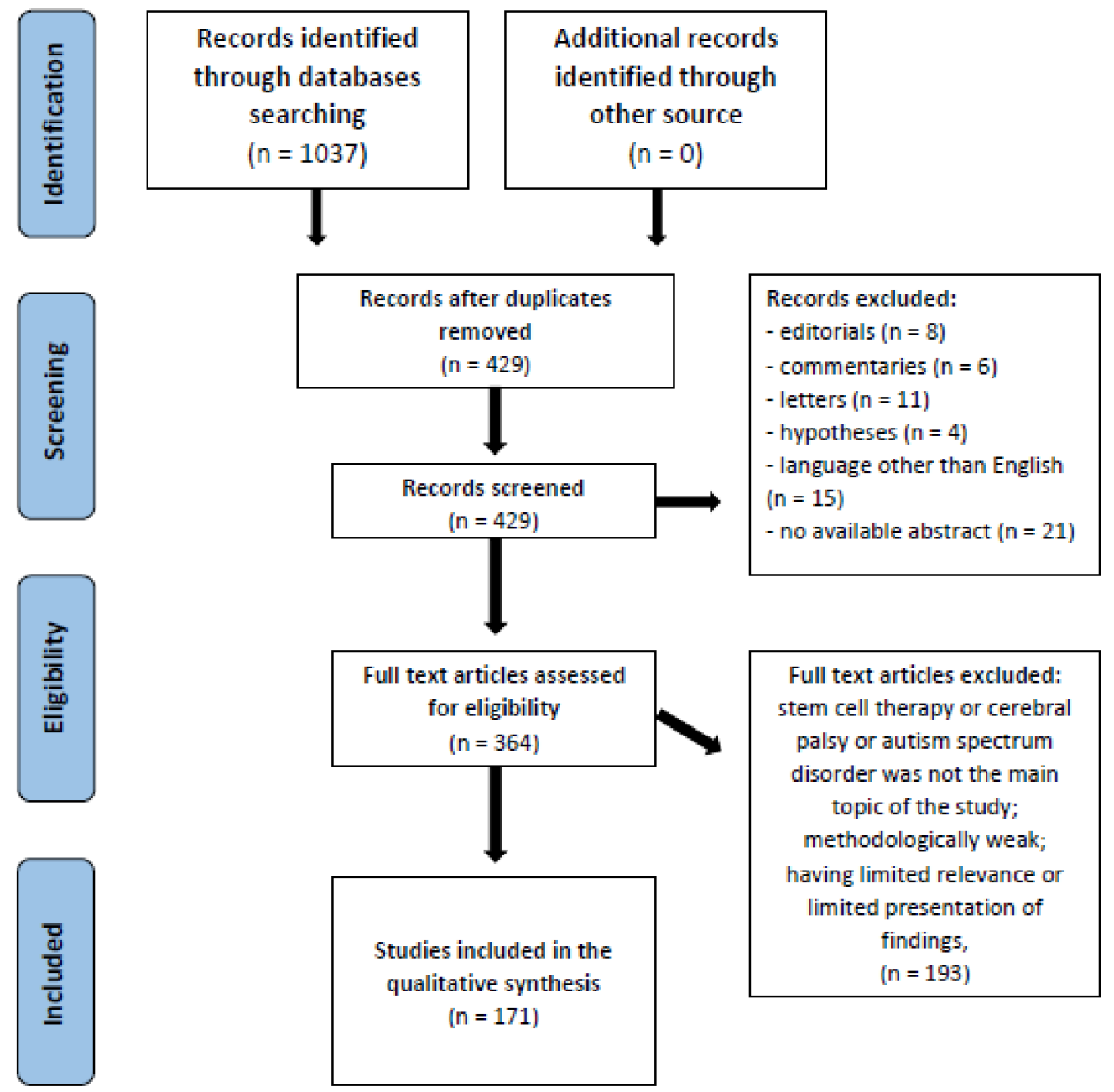

Figure 1. Flow diagram of PRISMA for the strategy research and selection processes for this review.

\subsection{Stem Cells Types}

Nowadays, many types of stem cells are known, differentiated mainly on the basis of the methods of obtaining them, their origin, and their mechanisms of action. Depending on what we want to achieve, we can use a specific type of stem cells in therapy, corresponding to the profile of action of our goals. In neurological diseases such as ASD or CP, we mainly rely on the use of paracrine effect on host cells, obtained through the influence of substances released from the obtained cells. Thus, host tissue cells are stimulated by cytokines and other mediators for repair processes. Mesenchymal stromal cells and cells from umbilical cord blood are most commonly used due to their good safety profiles, ease of accessibility for their procurement, and high efficacy.

Cord blood cells are among the most easily accessible stem cells. Their collection is a non-invasive method that does not endanger either the mother or her child. While the remaining blood in the umbilical cord is secured, a small amount of blood collected from the mother during delivery is sent for testing to exclude infectious diseases that could infect the recipient during cell transplantation [60]. Umbilical cord blood is an environment rich in diverse stem/progenitor cell populations that may act by different mechanisms that may complement each other, thus improving the effect achieved. In addition to hemopoietic stem and progenitor cells, cord blood also contains many other cells, including mesenchymal stromal cells (MSCs), endothelial progenitor cells, T regulatory cells, and monocyte-derived cells [60-63]. Cord blood cells exert paracrine effects that promote cell survival, stimulate proliferation and migration of neural stem cells (NSCs), induce regener- 
ation of damaged cells, reduce inflammation, and promote angiogenesis [62,64]. Compared to other types of stem cells, cells from cord blood have many advantages, especially in terms of their safety and efficacy [62,64-66], ethical aspects of their procurement [62,67], proliferation without risk of tumorigenesis (carcinogenesis), availability $[62,68,69]$, and regulation of immune response [62,64].

Another rich source of stem cells is bone marrow, but cells harvested from bone marrow have characteristics that distinguish them from those from cord blood. First of all, bone-marrow-derived cells from adults are more immunogenic and are more likely to carry latent viruses that are difficult to detect in assays [62,70]. Moreover, they are characterized by shorter telomeres and lower proliferative potential [62,70]. Bone marrow cells are harvested during a surgical procedure under general anesthesia that takes about an hour. The left or right posterior iliac crest is the most common site of harvest. The iliac crest is preferred for safety reasons because no major blood vessels or organs are located close to this area. A 1-1.5 L mixture of bone marrow and blood is taken from the bone, which regenerates within two weeks.

Mesenchymal stem cells (MSCs) are cells that, according to the International Society of Cellular Therapy (ISCT), are defined by the following minimal set of criteria: grown in adherence to plastic surface of dishes when maintained in standard culture conditions; express cytospecific cell surface markers, that is, CD105, CD90, and CD73, to be negative for other cell surface markers, that is, CD45, CD34, CD14, and CD11b; possess the capacity to differentiate into mesenchymal lineages under appropriate in vitro conditions [71,72]. MSCs show a high expansion potential, genetic stability, stable phenotype, high proliferation rate as adherent cells, and self-renewal capacity and can be easily collected and shipped from the laboratory to the bedside and are compatible with different delivery methods and formulations [72,73]. They can be isolated from many different sources such as bone marrow, cord blood, amniotic fluid, or even adipose tissue [72,74,75]. It is an extremely heterogeneous group of undifferentiated, mulipotent cells that have the ability to differentiate into various cell lineages [71-75]. Although these cells have been shown to mature predominantly into mesodermal tissue cells (such as chondrocytes, osteocytes, or adipocytes), in therapeutic use in CP or ASD, we place more hope on their paracrine abilities, whereby these cells are able to produce factors that activate endogenous restorative mechanisms in damaged tissues, contributing to the restoration of their lost functions [72,76-78]. The paracrine action of MSCs is mainly based on their ability to immunomodulate, initiate and promote angiogenesis, support the growth and differentiation of local stem cells, and, importantly, prevent apoptosis and chemoattraction of immune cells $[60,72,74,77,79]$. MSCs are able to inhibit the release of pro-inflammatory cytokines and block neutrophil recruitment, so, due to their immunosuppressive effects, we can use them for effective autologous treatment as well as for heterologous transplantation, in which they do not require pharmacological immunosuppression $[60,72,80]$. In addition, they exhibit the ability to modulate humoral immune response as well as cellular by inhibiting the proliferation and maturation of T cells, B cells, NK cells, dendritic cells, and microglia [60]. Due to the low immunogenicity of MSCs, expressed by the low expression of MHC class I molecules and the lack of expression of MHC class II molecules on their surface, these cells can be used completely safely in an allogeneic setting without the need for antigens with matching tissue compatibility between donor and recipient cell leukocytes $[60,81]$. MSCs differentiate according to signals from surrounding tissues and do not cause uncontrolled growth or tumor formation $[60,72,81]$. Treatment with MSCs is characterized by high safety as clearly shown in a meta-analysis and systematic review published in 2012, based on 36 studies conducted in 14 countries around the world, involving more than 1000 recipients with various diseases [60,82]. The studies included recipients suffering from cardiovascular, neurological, oncological, or metabolic diseases. Importantly, there were no acute in fusional toxicity organ system complications in response to mesenchymal stromal cell treatment [60,82]. Additionally, there were no treatment-related 
deaths or malignancies during the 5-year follow-up. The only adverse event was fever, which resolved spontaneously [60,82].

Among many cell types, neural stem cells (NSCs) and neural stem cell-like cells also have their place. These are multipotent stem cells, which have a much more limited ability to differentiate than the previously described cells; that is, they can only differentiate into neurons and glial cells $[60,83]$. Their actions are responsible, among other things, for the regeneration of nervous tissue by replacing damaged cells, promoting myelination, and secreting neurotrophic substances stimulating neurogenesis $[60,81,84]$. Their importance in the regeneration of damaged neuronal circuits has also been shown $[60,81,84]$. These cells are particularly considered as cell therapy material for the treatment of many disorders associated with neuronal or glial cell loss in such clinical entities as stroke, Parkinson's, Alzheimer's, and Huntington's disease; among patients suffering from multiple sclerosis or amyotrophic lateral sclerosis; and among individuals who have suffered spinal cord injuries, among others [60,85-87]. However, their extraction from neurogenic areas of the brain is very limited for obvious reasons, so alternative sources are being sought. One such readily available, safe, and ethically uncontroversial source for obtaining cells that can then be differentiated in vitro into neural cells is umbilical cord blood and Wharton's jelly from the umbilical cord $[75,88,89]$.

Induced pluripotent stem cells (iPSCs) are cells that have undergone in vitro deprogramming, making them capable of differentiating into all cells of the body $[81,90]$. They can be obtained after applying genetic engineering processes on already differentiated cells. Because of the way they are obtained, iPSCs are not problematic from a practical and ethical point of view; moreover, thanks to the possibility of using allogeneic transplantation, they do not generate anxiety related to its rejection [81,90]. Many ways of obtaining iPSCs are known. They can be divided into two main groups-the first, using viruses as carriers to introduce deprogramming factors (viral-based methods). and the second group, including methods without the use of viruses (non-viral methods) [81,91]. The use of viral vectors (e.g., lentiviruses or retroviruses) allows highly efficient incorporation of the transgene into the host genome and its expression [81,90]. However, this method also carries risks related to the danger of a random site of transgene incorporation and, under unfavorable conditions, the possibility of its reactivation, which increases the possibility of cancer development $[81,90]$. To minimize these risks, methods unrelated to integration into the host genome can be used, in which adenoviruses, polycistronicepisomal vectors, mRNA, miRNA, or T antigen of SV40 virus and reprogramming proteins are used [81,92-94]. Due to the ability of iPSCs to differentiate into neuronal lineage cells, therapy with these stem cells has been shown to be effective in neurological disorders such as Huntington Disease and amyotrophic lateral sclerosis $[95,96]$.

Table 1 provides a brief overview of the stem cell types mentioned above.

\subsection{Cell Therapies in Autism Spectrum Disorders (ASD)}

Stem cell therapy was commonly associated with hematological malignancies; however, in recent decades, it has been also applied to treat other conditions caused by dysfunction of the nervous system such as ASD. This kind of treatment seems to be an attractive therapy: with the enzyme replacement, it prevents the neurological degeneration process as well as extends life in ASD $[97,98]$. The beneficial effect of stem cell implementation comes from their ability to produce and release the chemokines, cytokines (e.g., anti-inflammatory IL-10 and IL-1Ra), and growth factors (e.g., transforming growth factor $\beta 1$, TGF- $\beta 1$ or granulocyte-macrophage colony-stimulating factor, GM-CSF), which decreases or stops the proinflammation [11,19-22,72,99]. 
Table 1. Different stem cells, related sources, and their mechanisms of action $[60-70,72-78,81,83,90]$.

\begin{tabular}{|c|c|c|}
\hline Type of Stem Cells & Source & Mechanism of Action \\
\hline Fetal stem cells & $\begin{array}{l}\text { Fetus, fetal blood, placenta, amniotic } \\
\text { membrane, amniotic fluid, umbilical cord }\end{array}$ & $\begin{array}{l}\text { Secretion of neurotrophic factors, } \\
\text { immunomodulatory capacities, suppression of } \\
\text { proinflammatory processes }\end{array}$ \\
\hline Mesenchymal stem cells & Bone marrow, umbilical cord & $\begin{array}{l}\text { Paracrine secretion of several } \\
\text { anti-inflammatory and survival-promoting } \\
\text { molecules (i.e., VEGF, HGF, BDNF, NGF), } \\
\text { neuroprotective effects, hypoimmunogenic and } \\
\text { immunosuppressive properties }\end{array}$ \\
\hline Neural stem cells & $\begin{array}{l}\text { Brain (subventricular zone of lateral } \\
\text { ventricles and subgranular zone of } \\
\text { hippocampus) }\end{array}$ & $\begin{array}{l}\text { Secretion of neurotrophic factors, maintenance } \\
\text { of homeostasis, neuroprotective effects, } \\
\text { differentiation into neural-type cells } \\
\text { Secretion of trophic factors }\end{array}$ \\
\hline Adipo-derived stem cells & Adipose tissue & $\begin{array}{l}\text { Immunosuppressive and } \\
\text { hypoimmunogenic effects }\end{array}$ \\
\hline $\begin{array}{l}\text { Umbilical cord- and amniotic } \\
\text { fluid-derived stem cells }\end{array}$ & Umbilical cord, placenta, amniotic fluid & $\begin{array}{l}\text { In vitro growth capacity, low immunogenicity } \\
\text { and immunomodulation properties }\end{array}$ \\
\hline Hematopoietic stem cells & Blood, bone marrow, umbilical cord & Paracrine activity \\
\hline Induced pluripotent stem cells & Any cell type & Differentiation capacity \\
\hline
\end{tabular}

Abbreviations: VEGF = vascular endothelial growth factor; HGF = hepatocyte growth factor; BDNF = brain-derived neurotrophic factor; $\mathrm{NGF}=$ nerve growth factor.

\subsubsection{Stem Cell Mechanism Actions in ASD}

The neuropathologies underlying ASD are still not fully known [60]; however, some of them have been already understood (dysfunction of immune system, cerebellum alterations, oxidative stress, hypoperfusion, decreased number of Purkinje cells, defective cortical organization and altered plasticity of dendritic spine morphology, etc.) [100,101]. In Table 2, the stem cell mechanisms of actions in ASD resulting in functional recovery and structural reorganization are provided.

Table 2. Stem cell mechanisms of action in ASD [102-106].

\begin{tabular}{|c|c|}
\hline Process & Mechanism of Action \\
\hline Reduction of inflammation & $\begin{array}{l}\text { - Immune modulation and neuroprotective effects } \\
\text { - Inhibition of microglial activation and reduction of proinflammatory } \\
\text { cytokinesproduction }[102,103,106,107]\end{array}$ \\
\hline Restoration of neural connectivity & $\begin{array}{l}\text { - Modulation of the excitation and inhibition of neurons by controlling the secretion of } \\
\text { neurotransmitters [107] } \\
\text { - } \quad \text { Re-establishment of neural connectivity by new synapse formation [10] }\end{array}$ \\
\hline Angiogenesis & $\begin{array}{l}\text { - } \quad \text { Reversion hypoxia caused by hypoperfusion in autism } \\
\text { - Paracrine activity stimulation endogenous cells, promotion of angiogenesis and } \\
\text { - } \quad \text { differentiation of endothelial cells } \\
\text { Formation of new blood vessels reverse hypoxia [105] }\end{array}$ \\
\hline Antioxidant activity & - $\quad$ Reduction of the superoxide production [105] \\
\hline
\end{tabular}

3.2.2. Clinical Studies and the Symptoms Improvement in ASD after Stem Cell Therapy

Currently, there is still a strong need for supporting scientific data in stem cell therapy use in ASD, firstly, to ensure the safety of such treatment and subsequently prove the legitimacy of the use, which will be confirmed by the improvement of the patients condition. The necessity for further data collection results from the fact that various stem cell types differ from each other, and this will result in another route of administration 
(intravenous/intrathecal), dosage, and duration of treatment. Additionally, the time of follow-up needs to be more standardized as only then allows to assess the long-term outcomes and the choice of multiple timely transplantations [81].

A clinical study examining the efficacy of autologous bone marrow mononuclear cell transplantation (BMMNC) in thirty children who fulfilled the autism criteria with Childhood Autism Rating Scale (CARS) scores $>37$ reported a significant reduction in the severity of ASD with the median CARS score decreasing from 50 (range 40-55.5) to 46.5 (range 33.5-53.5) $(p<0$.05) [108]. Another study assessing the (BMMNC) transplantation infused via the intrathecal route in 32 children with ASD noticed improvements in speech, language patterns, social relationships, and brain metabolism. Out of 32 patients, a total of $29(91 \%)$ patients improved on total Indian Scale for Assessment of Autism (ISAA) scores and 20 patients (62\%) showed decreased severity on the Clinical Global Impression Scale (CGI-I scale) and global improvement up to $96 \%$ of patients on CGI-II $(p<0.001)$ [109]. According to different research examining the potential in alleviating ASD symptoms by modulating inflammatory processes in the brain using umbilical-cord-blood-derived cell therapy conducted on twenty-five children with a median age of 4.6 years, significant improvements were reported in behavior in the first 6 months post-infusion, which were also sustained at 12 months. It was noted that the improvements were greater in children with higher baseline nonverbal intelligence quotients [110]. The clinical studies mentioned above reported no severe adverse events after cell transplantation and encountered only minor adverse events, such as nausea, vomiting, and pain at the site of injection [108-110].

The encouraging results of these clinical trials provide us with future directions for the application of cellular therapy in autism. However, it needs to be emphasized that overall clinical outcome cannot be fully beneficial without the addition of neurorehabilitation such as behavioral and speech therapy, sensory integration, or psychological intervention, etc., which enhances the efficacy of stem cell therapy in ASD.

Table 3 provides a brief overview of clinical trials of stem cell therapies for ASD conducted in recent years.

Table 3. Clinical trials of cell therapies in autism spectrum disorder.

\begin{tabular}{|c|c|c|c|c|c|c|}
\hline Authors & Year & Study Design & Sample & $\begin{array}{c}\text { Patient Age } \\
\text { (Years) }\end{array}$ & Cell Source & $\begin{array}{c}\text { Route of } \\
\text { Administration }\end{array}$ \\
\hline Sun et al. [22] & 2020 & Singlearm,openlabel & 12 & $4-9$ & AlloUC & i.v. \\
\hline & & & & & $\begin{array}{l}\text { Autologous or } \\
\text { allogeneic CB }\end{array}$ & \\
\hline \multirow[t]{6}{*}{ Dawson et al. [111] } & 2020 & $\mathrm{RCT}$ & 180 & $2-7$ & $\begin{array}{l}\text { Autologous or } \\
\text { allogeneic CB }\end{array}$ & i.v. \\
\hline & & & & & Autologous or & \\
\hline & & & & & allogeneic CB & \\
\hline & & & & & Autologous or & \\
\hline & & & & & allogeneic CB & \\
\hline & & & & & Auto or Allo CB & \\
\hline Riordan et al. [27] & 2019 & Singlearm,openlabel & 20 & $6-15$ & Allo UC & i.v. \\
\hline Chez et al. [112] & 2018 & $\mathrm{RCT}$ & 29 & $2-6$ & AutoCB & i.v. \\
\hline Dawson et al. [110] & 2017 & Singlearm,openlabel & 25 & $2-5$ & Auto CB & i.v. \\
\hline
\end{tabular}

Abbreviations: $\mathrm{CBMNC}=$ cord blood mononuclear cells; UC-MSC = umbilical cord derived mesenchymal stromal cells; $\mathrm{BM}-\mathrm{MSC}=$ bone marrow-derived mesenchymal stromal cells; $\mathrm{RCT}=$ randomized controlled trial; $\mathrm{CB}=\mathrm{umbilical}$ cord blood; i.v. = intravenous administration.

\subsubsection{Limitations}

Undoubtedly, stem cell therapy in ASD poses a promising therapeutic option for patients suffering from this condition however, several limitations can be distinguished to establish a final opinion on this treatment. It is worth starting with specifying the conditions for carrying out such therapy, which must be performed according to the clinical guidelines and under laboratory conditions [81]. In addition, there are several other criteria that must be fulfilled that apply especially to the ethical requirements listed in Table $4[81,113]$. 
Table 4. Ethical requirements in ASD stem cell therapy.

\begin{tabular}{c}
\hline Patient-informed consent for treatment \\
\hline Indications/contraindications for treatment \\
\hline Documentation of procedure and therapy \\
\hline Safety and efficacy evaluations \\
\hline Policy of repeated treatments \\
\hline Not charging patients for unproven therapies \\
\hline Basic principles of cell therapy \\
\hline Policy of repeated treatments \\
Publishing responsibility
\end{tabular}

Another set of issues concern the insufficient number of studies and subjects included. The samples are not numerous and need to be more standardized, which also makes it difficult to express an unambiguous position. The next debatable point includes reported trials evaluating the efficacy by the use of different scales and scores, which should be preferably standardized as well as internationally validated to ensure the most reliable data. However, dose determination and cell source remain the most challenging. Various studies indicate different effective dosages, which also should be determined with an indication of the cell type therapeutic potential differs according to its source. Considering the limitations mentioned above, large clinical trials are still required to collect more exhaustive data to clearly establish the safety and efficacy of stem cell therapy in ASD.

\subsection{Stem Cells in Cerebral Palsy Therapy}

Cerebral palsy (CP), as mentioned above in the Introduction section, is a group of disorders caused by some insult to the matter of a developing brain. The disorders affect patient's movement, balance, sensory abilities, and posture. Clinical picture of discussed disease may vary depending on the severity of the damage as well as its location. The vast majority of the cases are connected to perinatal period, whereas only about $8 \%$ of cerebral palsy patients have acquired it later on in life [34].

Diagnosis

The diagnosis is made based on five crucial elements:

1. The disease covers a spectrum of symptoms;

2. Though the disorder is permanent, itis not unchangeable;

3. The disorder involves either movement or/and posture problems next to motor function issues;

4. The cause in a non-progressive interference, lesion or abnormality;

5. The cause indicated in point 4 arose in a developing or immature brain. [114]

One should not forget that each $\mathrm{CP}$ case is a different individual; therefore, certain inclusion or exclusion criteria may apply.

Gross Motor Classification System

The most commonly used scale in estimating the influence of the disorder on patient's abilities, and hence their possible improvement after treatment, is Gross Motor Function Classification System, later called GMFCS [36,46,65,115-118]. It consists of five-level grading system that describes gross motor functions of affected individual [119-121]. Levels of Gross Motor Classification System are shown in Table 5. 
Table 5. Gross Motor Classification System.

Level I

Level II

Level III

Level IV

Level V

The child's abilities to walk, run, climb the stairs, and jump without any helpthough their balance, coordination, and speed are compromised.

The child is usually able to walk, sometimes needing some assistance, and needs a railing while climbing the stairs. Difficulties occur while walking a long distance or in challenging surroundings. Gross motor skills are minimal.

The child can walk with a mobility device. Climbing the stairs requires the use of a railing and some assistance. Forlong distances, a wheelchair is used.

The child requires physical assistance and power mobilities. They may be able to walk short distances with appropiate support.

The child uses a wheelchair in all surroundings. They have problems with positioning and controling movements of their head, trunk, and extremities.

Gross Motor Function Measure

GMFM- 88 and its shorter version, GMFM-66, are also often come across when delving into the topic of $\mathrm{CP}$. The test checks developmental milestones of a child divided into five categories:

1. Lying and rolling

2. Sitting

3. Crawling and kneeling

4. Standing

5. Walking, running and jumping [122].

\subsubsection{Stem Cells}

Multidisciplinary care is required to minimize the consequences of cerebral palsy. Aside from long-used therapies, such as intense rehabilitation, spasticity-relieving treatments, sensory and cognitive therapies, and surgical interventions, another innovative approach has been found. Stem cell (SC) therapy has proven promising in various neurological disorders [119]. Surely, scientists' attention has turned toward CP. Stem cells have been frequently used in several disease in the past years. Taking into consideration that brain damage in $\mathrm{CP}$ is non-progressive and usually restricted to a few cell types, one may suspect that stem cells can improve the situation. The fact that another cause of the disease may be demyelination from olygodendrocyte loss suggests this even more, when one remembers that SC have been widely used in the treatment of other diseases based on the same problem $[119,123]$. The mechanisms in which SCs may be able to help improve the $\mathrm{CP}$ patients' quality of life are due to their regenerative abilities. Once engrafted, the transplanted cells can proliferate. SCs also have anti-inflammatory qualities as they cause a reduction in the number of excitotoxins, cytotoxins, and oxygen free radicals. Their trophic abilities can reestablish balance between neurotrophic factors [65]. There are a lot of stem cell types with promising qualities in the treatment of cerebral palsy [65]. They are enumerated in Table 6.

While a wide range of stem-cell derivation sources are available, the main five sources are predominantly used in attempts to treat patients with $\mathrm{CP}$. These include bone marrow [58,124,125], human umbilical cord blood(hUCB)/umbilical cord (UC) [46,89], fetal brain $[117,126]$, fat, and peripheral blood [52,127]. Stem cells are often derived from an autologous source. However, in children with cerebral palsy, it should be mentioned that autologous bone marrow stem cells are not a good choice as tissue harvesting can cause great physical and psychological trauma to children [56]. Furthermore, in the case of children with cerebral palsy, the fact that all stem cells of allogeneic origin show low immunogenicity, which effectively prevents immune rejection, also gives reasonto abandon the autologous source [67]. It is important to recognize that stem cells from different sources have different efficacy, but interestingly, even stem cells from the same source vary in efficacy during treatment [56]. In 2017, a study was conducted comparing the effectiveness of bone marrow mononuclear stem cells (BMMNCs) and bone marrow MSCs in the treatment 
of cerebral palsy [42]. This study showed that in children with $\mathrm{CP}$, treatment with bone marrow MSCs was more effective than with BMMNCs [42]. It seems logical that the use of neural stem cells is an ideal option for the treatment of damaged neurons, as well as their extraction from the fetal brain, which is their optimal source, but this solution is still controversial due to ethical issues $[56,117,126]$.

Table 6. Stem cell types promising in the treatment of cerebral palsy.

\begin{tabular}{c}
\hline HAECS-amnion epithelial cells \\
\hline CD34—expressing cells from umbilical cord blood \\
\hline ES—embryonic stem cells \\
\hline Fetal stem cells \\
\hline IPS cells—induced pluripotent stem cells \\
\hline MSCs-mesenchymal stem cells \\
\hline MAPCs—multipotent adult progenitor cells \\
\hline Olfactory ensheathing cells \\
\hline OPCs-olygodendrocyte progenitor cells \\
Human UCB-umbilical cord blood
\end{tabular}

Table 7 provides a brief overview of published clinical trials of stem cell therapies for $\mathrm{CP}$ conducted in recent years.

Table 7. Clinical trials of cell therapies in CP.

\begin{tabular}{ccccccc}
\hline Authors & Year & Study Design & Sample & $\begin{array}{c}\text { Patient Age } \\
\text { (Years) }\end{array}$ & Cell Source & $\begin{array}{c}\text { Route of } \\
\text { Administration }\end{array}$ \\
\hline Guetal. [36] & 2020 & RCT & 40 & $2-12$ & Allo UC & i.v. \\
Huang et al. [46] & 2018 & RCT & 56 & $3-12$ & Allo CB & i.v. \\
Liu et al. [42] & 2017 & RCT & 105 & $6 m 0-12$ & Auto BM & Intrathecal \\
Rah et al. [52] & 2017 & RCT & 57 & $2-10$ & Auto PB & i.v. \\
Sun et al. [41] & 2017 & RCT & 63 & $1-6$ & Auto CB & i.v. \\
\hline
\end{tabular}

Abbreviations: CB-MSC = cord blood-derived mesenchymal stromal cells; BM-MSC = bone marrow-derived mesenchymal stromal cells; $\mathrm{BM}-\mathrm{MNC}=$ bone marrow mononuclear cells; $\mathrm{NPC}=$ neural progenitor cells; $\mathrm{CB}=$ umbilical cord blood; $\mathrm{PBMNC}=$ peripheral blood mononuclear cells; i.v. $=$ intravenous administration; $\mathrm{mo}=$ months.

\subsubsection{Route of Administration}

We distinguish between more and less invasive methods of stem cell administration. The most common are intravenous injection and lumbar puncture [56]. A method using stereotactic brain surgery is also available, but it is less frequently used due to its high invasiveness, by which its side effects are relatively serious, such as damage to blood vessels of the lateral ventricle [128], which can cause brain damage, thus counteracting the therapeutic effects of stem cells [128]. Intravenous administration of stem cells has limited efficacy due to the blood-brain barrier; thus only a small proportion of stem cells can enter the brain parenchyma $[56,129]$. Thus, regeneration and differentiation of exogenous stem cells in the brain is less efficient [129]. When administered by lumbar puncture, therapeutic agents can reach the brain via the cerebrospinal fluid circulation [130]. Stem cells are also known to be applied via the intranasal route, where the administered cells bypass the blood-brain barrier and enter the brain through the perinuclear space between the somatosensory plate and the olfactory nerve [131,132]. 


\subsubsection{Effectiveness}

Research has shown that SC therapy is effective in children with CP, yet it is not spectacular. Children with the first or the second level of GMFCS do not seem to benefit from SC infusion. However, children with severe CP did show an improvement in gross motor skills, according to GMFCS and GMFM-88/66. The dosage of the SC infusion varied from $4 \times 10^{6}$ to $6 \times 10^{8}$. SCs were administered mostly intravenously $[36,46,116]$. The 2012 research performed an infusion of 8-10 $\times 10^{6}$ NPCs in $200 \mathrm{ul} \mathrm{normal} \mathrm{saline} \mathrm{into} \mathrm{the}$ lateral ventricle, which caused a major improvement in the first months after receiving treatment. The improvement gradually slowed down; patients did not reach regression. This observation gives an idea of multiple transplants, repeated periodically [117]. Patients aged 3 to 18 years old taking part in a 2018 study received four infusions. According to their GMFM-88 and Comprehensive Functional Assessment, their gross motor and cognitive skills were significantly higher than those in a control group during the while follow-up period, which lasted 24 months, even though both control and researched groups were continually rehabilitated [46]. A study from 2019 suggests that higher dosage correlates with an improved motor outcome [116]. Language improvements have not been observed, but it may be caused by the fact that the treatment has been implemented after the crucial phase in children's speech development [115]. Language difficulties usually consist of asophia, anarthria, and developmental delays. Children receiving four infusions of hUCMSCs in a 2020 trial underwent a 12-month-long follow-up and showed a significant improvement in CFA, GMFM, and Activities of Daily Life- ADL. Moreover, their IL-1alpha, IL-6, and TNF- beta were decreased after the transplant, which supports the statement that SCs have anti-inflammatory abilities [36,65]. A peak improvement was noted at six months after the transplant. This study also used an unusual method of monitoring the group's improvement, as they measured the metabolic activity in the brain. The standard uptake of Fluorine was increased in 3 out of 5 patients. This indicates a recovery in their cerebral metabolic activity based on regional glucose metabolism [36]. According to a case-series of 17 patients, the SC therapy proved effective in $73 \%$ of the cases [118].

\subsubsection{Safety}

The main cause of worries when implementing this treatment is the fear of SCs causing neoplasms in the future. These cells have the ability to induce angiogenesis, which is also a red light when thinking about possible oncogenesis [65,118]. Nevertheless, none of cited papers have mentioned the occurrence of such an adverse event. Reported Severe Adverse Events (SAEs) included infections and seizures coming up equally in both research and control groups. The majority of patients had an uneventful post-injection course or presented mild adverse events such as diarrhea, which proved the therapy's short-time safety $[46,116,118]$.

\subsubsection{Adverse Effects}

What scientists always look for, apart from the effectiveness of a given method, are its side effects. In the studies conducted, side effects did occur, but most were mild and transient in nature and were treated symptomatically if necessary [56]. Often, the side effects were related to the way the stem cells were administered, such as pain and redness at the injection site, back pain, and neck stiffness (especially after lumbar puncture) $[52,56,58,124,128,133-135]$. The most common side effects include fever, nausea, vomiting, upper respiratory infections, and diarrhea [52,56,58,124,128,133-135]. The most serious side effects were laryngeal stridor and swelling of the tongue $[56,134]$, as well as seizures (however, these patients had already experienced seizures before the stem cell treatment) $[124,135]$. It is exceptionally interesting that patients who had refractory epilepsy or drug-resistant epilepsy, after being given stem cells as a treatment for cerebral palsy, showed less susceptibility to epileptic seizures than before [136,137]. This interesting lead should prompt researchers and clinicians to further explore the use of stem cell therapy in the treatment of epilepsy. 


\section{Conclusions}

It is certain that in the coming years we will witness a gradual expansion of the influence of stem cells in the field of treatment of neurodevelopmental diseases such as cerebral palsy and autism spectrum disorder. It is safe to say that stem cell therapies are a promising novel treatment tool and have potential therapeutic targets based on their excellent regenerative abilities and immunomodulatory effect. Due to the numerous discrepancies in clinical studies concerning the route of administration, cell source, and doses used, it is currently difficult to develop a well-defined consensus of practice in order to maximize therapeutic effect while limiting side effects. Probably one of the most interesting and important aspects is the long-term safety and efficacy of stem cell therapy in ASD and CP. Further studies on the pediatric population are warranted, because still little is known about long-term outcomes and the follow-up period after the current clinical trials is generally short, so the long-term safety and efficacy of stem cell therapy still need to be adequately evaluated.

Author Contributions: Conceptualization was performed by J.P. Methodology was performed by K.K., S.K., K.S., J.P. Software by K.K., S.K., K.S., J.P. Validation was performed by K.K., S.K., K.S., J.P. Formal analysis was performed by J.P. Investigation was performed by K.K., S.K., K.S., J.P. Resources were provided by K.K., S.K., K.S., J.P. Data curation was performed by K.K., S.K., K.S., J.P. Writing—original draft preparation was performed by K.K., S.K., K.S., J.P. Writing-review and editing was performed by K.K., S.K., K.S., J.P., E.E.-W. Visualization was performed by K.K., S.K., K.S., J.P. Supervision was performed by J.P. Project administration was performed by J.P. Funding acquisition was performed by J.P., E.E.-W. All authors have read and agreed to the published version of the manuscript.

Funding: This research received no external funding.

Institutional Review Board Statement: Not applicable.

Informed Consent Statement: Not applicable.

Data Availability Statement: Not applicable.

Conflicts of Interest: The authors declare no conflict of interest.

\section{References}

1. American Psychiatric Association. Diagnostic and Statistical Manual of Mental Disorders, 5th ed.; American Psychiatric Association: Washington, DC, USA, 2013. [CrossRef]

2. World Health Organization (Ed.) The ICD-10 Classification of Mental and Behavioural Disorders: Diagnostic Criteria for Research; World Health Organization: Geneva, Switzerland, 1993; ISBN 978-92-4-154455-9.

3. Roman-Urrestarazu, A.; van Kessel, R.; Allison, C.; Matthews, F.E.; Brayne, C.; Baron-Cohen, S. Association of Race/Ethnicity and Social Disadvantage with Autism Prevalence in 7 million School Children in England. JAMA Pediatr. 2021, 175, e210054. [CrossRef]

4. Morales Hidalgo, P.; Voltas Moreso, N.; Canals Sans, J. Autism spectrum disorder prevalence and associated sociodemographic factors in the school population: EPINED study. Autism 2021, 25, 1999-2011. [CrossRef] [PubMed]

5. Toro, R.; Konyukh, M.; Delorme, R.; Leblond, C.; Chaste, P.; Fauchereau, F.; Coleman, M.; Leboyer, M.; Gillberg, C.; Bourgeron, T. Key role for gene dosage and synaptic homeostasis in autism spectrum disorders. Trends Genet. 2010, 26, 363-372. [CrossRef]

6. De la Torre-Ubieta, L.; Won, H.; Stein, J.L.; Geschwind, D.H. Advancing the understanding of autism disease mechanisms through genetics. Nat. Med. 2016, 22, 345-361. [CrossRef]

7. Sahin, M.; Sur, M. Genes, circuits, and precision therapies for autism and related neurodevelopmental disorders. Science 2015, 350, 6263. [CrossRef] [PubMed]

8. Schaefer, G.B. Clinical Genetic Aspects of Autism Spectrum Disorders. Int. J. Mol. Sci. 2016, 17, 180. [CrossRef]

9. El-Fishawy, P.; State, M.W. The genetics of autism: Key issues, recent findings, and clinical implications. Psychiatr. Clin. N. Am. 2010, 33, 83-105. [CrossRef]

10. Mandy, W.; Lai, M.C. Annual Research Review: The role of the environment in the developmental psychopathology of autism spectrum condition. J. Child Psychol. Psychiatry 2016, 57, 271-292. [CrossRef] [PubMed]

11. Onore, C.; Careaga, M.; Ashwood, P. The role of immune dysfunction in the pathophysiology of autism. Brain Behav. Immun. 2012, 26, 383-392. [CrossRef]

12. Grabrucker, A.M. Environmental factors in autism. Front. Psychiatry 2013, 3, 118. [CrossRef] 
13. Cauvet, É.; Van't Westeinde, A.; Toro, R.; Kuja-Halkola, R.; Neufeld, J.; Mevel, K.; Bölte, S. Sex Differences Along the Autism Continuum: A Twin Study of Brain Structure. Cereb. Cortex 2019, 29, 1342-1350. [CrossRef]

14. Santini, E.; Klann, E. Reciprocal signaling between translational control pathways and synaptic proteins in autism spectrum disorders. Sci. Signal. 2014, 7, re10. [CrossRef] [PubMed]

15. Gao, R.; Penzes, P. Common mechanisms of excitatory and inhibitory imbalance in schizophrenia and autism spectrum disorders. Curr. Mol. Med. 2015, 15, 146-167. [CrossRef] [PubMed]

16. Volk, L.; Chiu, S.L.; Sharma, K.; Huganir, R.L. Glutamate synapses in human cognitive disorders. Annu. Rev. Neurosci. 2015, 38, 127-149. [CrossRef] [PubMed]

17. Wolff, J.J.; Gu, H.; Gerig, G.; Elison, J.T.; Styner, M.; Gouttard, S.; Botteron, K.N.; Dager, S.R.; Dawson, G.; Estes, A.M.; et al. Differences in white matter fiber tract development present from 6 to 24 months in infants with autism. Am. J. Psychiatry 2012, 169, 589-600. [CrossRef]

18. Young, A.M.; Chakrabarti, B.; Roberts, D.; Lai, M.C.; Suckling, J.; Baron-Cohen, S. From molecules to neural morphology: Understanding neuroinflammation in autism spectrum condition. Mol. Autism 2016, 7, 9. [CrossRef]

19. Takano, T. Role of Microglia in Autism: Recent Advances. Dev. Neurosci. 2015, 37, 195-202. [CrossRef]

20. Zantomio, D.; Chana, G.; Laskaris, L.; Testa, R.; Everall, I.; Pantelis, C.; Skafidas, E. Convergent evidence for mGluR5 in synaptic and neuroinflammatory pathways implicated in ASD. Neurosci. Biobehav. Rev. 2015, 52, 172-177. [CrossRef]

21. Goines, P.E.; Ashwood, P. Cytokine dysregulation in autism spectrum disorders (ASD): Possible role of the environment. Neurotoxicol. Teratol. 2013, 36, 67-81. [CrossRef]

22. Sun, J.M.; Dawson, G.; Franz, L.; Howard, J.; McLaughlin, C.; Kistler, B.; Waters-Pick, B.; Meadows, N.; Troy, J.; Kurtzberg, J. Infusion of human umbilical cord tissue mesenchymal stromal cells in children with autism spectrum disorder. Stem Cells Transl. Med. 2020, 9, 1137-1146. [CrossRef] [PubMed]

23. Herbert, M.R. Contributions of the environment and environmentally vulnerable physiology to autism spectrum disorders. Curr. Opin. Neurol. 2010, 23, 103-110. [CrossRef]

24. Kępka, A.; Ochocińska, A.; Chojnowska, S.; Borzym-Kluczyk, M.; Skorupa, E.; Knaś, M.; Waszkiewicz, N. Potential Role of L-Carnitine in Autism Spectrum Disorder. J. Clin. Med. 2021, 10, 1202. [CrossRef]

25. Volkmar, F.R.; McPartland, J.C. From Kanner to DSM-5: Autism as an evolving diagnostic concept. Annu Rev. Clin. Psychol. 2014, 10, 193-212. [CrossRef] [PubMed]

26. Sanchack, K.E.; Thomas, C.A. Autism Spectrum Disorder: Primary Care Principles. Am. Fam. Phys. 2016, 94, 972-979.

27. Riordan, N.H.; Hincapié, M.L.; Morales, I.; Fernández, G.; Allen, N.; Leu, C.; Madrigal, M.; Paz Rodríguez, J.; Novarro, N. Allogeneic Human Umbilical Cord Mesenchymal Stem Cells for the Treatment of Autism Spectrum Disorder in Children: Safety Profile and Effect on Cytokine Levels. Stem Cells Transl. Med. 2019, 8, 1008-1016. [CrossRef] [PubMed]

28. Bhat, S.; Acharya, U.R.; Adeli, H.; Bairy, G.M.; Adeli, A. Autism: Cause factors, early diagnosis and therapies. Rev. Neurosci. 2014, 25, 841-850. [CrossRef] [PubMed]

29. Dawson, G.; Rogers, S.; Munson, J.; Smith, M.; Winter, J.; Greenson, J.; Donaldson, A.; Varley, J. Randomized, controlled trial of an intervention for toddlers with autism: The Early Start Denver Model. Pediatrics 2010, 125, e17-e23. [CrossRef]

30. Park, S.Y.; Cervesi, C.; Galling, B.; Molteni, S.; Walyzada, F.; Ameis, S.H.; Gerhard, T.; Olfson, M.; Correll, C.U. Antipsychotic Use Trends in Youth with Autism Spectrum Disorder and/or Intellectual Disability: A Meta-Analysis. J. Am. Acad. Child. Adolesc. Psychiatry 2016, 55, 456-468.e4. [CrossRef] [PubMed]

31. Nevels, R.M.; Dehon, E.E.; Alexander, K.; Gontkovsky, S.T. Psychopharmacology of aggression in children and adolescents with primary neuropsychiatric disorders: A review of current and potentially promising treatment options. Exp. Clin. Psychopharmacol. 2010, 18, 184-201. [CrossRef]

32. Sharma, S.R.; Gonda, X.; Tarazi, F.I. Autism Spectrum Disorder: Classification, diagnosis and therapy. Pharmacol. Ther. 2018, 190, 91-104. [CrossRef]

33. Vankeshwaram, V.; Maheshwary, A.; Mohite, D.; Omole, J.A.; Khan, S. Is Stem Cell Therapy the New Savior for Cerebral Palsy Patients? A Review. Cureus 2020, 12, e10214. [CrossRef] [PubMed]

34. Vitrikas, K.; Dalton, H.; Breish, D. Cerebral Palsy: An Overview. Am. Fam. Physician 2020, 101, 213-220. [PubMed]

35. Colver, A.; Fairhurst, C.; Pharoah, P.O. Cerebral palsy. Lancet 2014, 383, 1240-1249. [CrossRef]

36. Gu, J.; Huang, L.; Zhang, C.; Wang, Y.; Zhang, R.; Tu, Z.; Wang, H.; Zhou, X.; Xiao, Z.; Liu, Z.; et al. Therapeutic evidence of umbilical cord-derived mesenchymal stem cell transplantation for cerebral palsy: A randomized, controlled trial. Stem Cell Res. Ther. 2020, 11, 43. [CrossRef] [PubMed]

37. Richards, C.L.; Malouin, F. Cerebral palsy: Definition, assessment and rehabilitation. In Handbook of Clinical Neurology; Elsevier: Amsterdam, The Netherlands, 2013; Volume 111, pp. 183-195. [CrossRef]

38. Novak, I.; Hines, M.; Goldsmith, S.; Barclay, R. Clinical prognostic messages from a systematic review on cerebral palsy. Pediatrics 2012, 130, e1285-e1312. [CrossRef]

39. Kaminiów, K.; Kozak, S.; Paprocka, J. Neonatal Seizures Revisited. Children 2021, 8, 155. [CrossRef]

40. Graham, H.K.; Rosenbaum, P.; Paneth, N.; Dan, B.; Lin, J.P.; Damiano, D.L.; Becher, J.G.; Gaebler-Spira, D.; Colver, A.; Reddihough, D.S.; et al. Cerebral palsy. Nat. Rev. Dis. Primers 2016, 2, 15082. [CrossRef] [PubMed] 
41. Sun, J.M.; Song, A.W.; Case, L.E.; Mikati, M.A.; Gustafson, K.E.; Simmons, R.; Goldstein, R.; Petry, J.; McLaughlin, C.; WatersPick, B.; et al. Effect of Autologous Cord Blood Infusion on Motor Function and Brain Connectivity in Young Children with Cerebral Palsy: A Randomized, Placebo-Controlled Trial. Stem Cells Transl. Med. 2017, 6, 2071-2078. [CrossRef]

42. Liu, X.; Fu, X.; Dai, G.; Wang, X.; Zhang, Z.; Cheng, H.; Zheng, P.; An, Y. Comparative analysis of curative effect of bone marrow mesenchymal stem cell and bone marrow mononuclear cell transplantation for spastic cerebral palsy. J. Transl. Med. 2017, 15, 48. [CrossRef]

43. Hasegawa, J.; Toyokawa, S.; Ikenoue, T.; Asano, Y.; Satoh, S.; Ikeda, T.; Ichizuka, K.; Tamiya, N.; Nakai, A.; Fujimori, K.; et al. Relevant Obstetric Factors for Cerebral Palsy: From the Nationwide Obstetric Compensation System in Japan. PLoS ONE 2016, 11, e0148122. [CrossRef]

44. He, P.; Chen, G.; Wang, Z.; Guo, C.; Zheng, X. Children with motor impairment related to cerebral palsy: Prevalence, severity and concurrent impairments in China. J. Paediatr. Child. Health 2017, 53, 480-484. [CrossRef] [PubMed]

45. Oskoui, M.; Coutinho, F.; Dykeman, J.; Jetté, N.; Pringsheim, T. An update on the prevalence of cerebral palsy: A systematic review and meta-analysis. Dev. Med. Child. Neurol. 2013, 55, 509-519. [CrossRef] [PubMed]

46. Huang, L.; Zhang, C.; Gu, J.; Wu, W.; Shen, Z.; Zhou, X.; Lu, H. A Randomized, Placebo-Controlled Trial of Human Umbilical Cord Blood Mesenchymal Stem Cell Infusion for Children with Cerebral Palsy. Cell Transplant. 2018, 27, 325-334. [CrossRef] [PubMed]

47. Paneth, N.; Hong, T.; Korzeniewski, S. The descriptive epidemiology of cerebral palsy. Clin. Perinatol. 2006, 33, 251-267. [CrossRef]

48. Nelson, K.B.; Blair, E. Prenatal Factors in Singletons with Cerebral Palsy Born at or near Term. N. Engl. J. Med. 2015, 373, 946-953. [CrossRef]

49. MacLennan, A.H.; Thompson, S.C.; Gecz, J. Cerebral palsy: Causes, pathways, and the role of genetic variants. Am. J. Obstet. Gynecol. 2015, 213, 779-788. [CrossRef]

50. O'Callaghan, M.E.; MacLennan, A.H.; Gibson, C.S.; McMichael, G.L.; Haan, E.A.; Broadbent, J.L.; Goldwater, P.N.; Dekker, G.A. Epidemiologic associations with cerebral palsy. Obstet. Gynecol. 2011, 118, 576-582. [CrossRef]

51. Novak, I.; Morgan, C.; Adde, L.; Blackman, J.; Boyd, R.N.; Brunstrom-Hernandez, J.; Cioni, G.; Damiano, D.; Darrah, J.; Eliasson, A.C.; et al. Early, Accurate Diagnosis and Early Intervention in Cerebral Palsy: Advances in Diagnosis and Treatment. JAMA Pediatr. 2017, 171, 897-907. [CrossRef]

52. Rah, W.J.; Lee, Y.H.; Moon, J.H.; Jun, H.J.; Kang, H.R.; Koh, H.; Eom, H.J.; Lee, J.Y.; Lee, Y.J.; Kim, J.Y.; et al. Neuroregenerative potential of intravenous G-CSF and autologous peripheral blood stem cells in children with cerebral palsy: A randomized, double-blind, cross-over study. J. Transl. Med. 2017, 15, 16. [CrossRef]

53. Fan, H.C.; Ho, L.I.; Chi, C.S.; Cheng, S.N.; Juan, C.J.; Chiang, K.L.; Lin, S.Z.; Harn, H.J. Current proceedings of cerebral palsy. Cell Transplant. 2015, 24, 471-485. [CrossRef]

54. Kiasatdolatabadi, A.; Lotfibakhshaiesh, N.; Yazdankhah, M.; Ebrahimi-Barough, S.; Jafarabadi, M.; Ai, A.; Sadroddiny, E.; Ai, J The Role of Stem Cells in the Treatment of Cerebral Palsy: A Review. Mol. Neurobiol. 2017, 54, 4963-4972. [CrossRef] [PubMed]

55. Andrzejewska, A.; Dabrowska, S.; Lukomska, B.; Janowski, M. Mesenchymal Stem Cells for Neurological Disorders. Adv. Sci. 2021, 8, 2002944. [CrossRef]

56. Lv, Z.Y.; Li, Y.; Liu, J. Progress in clinical trials of stem cell therapy for cerebral palsy. Neural Regen. Res. 2021, 16, 1377-1382. [CrossRef]

57. Boncoraglio, G.B.; Ranieri, M.; Bersano, A.; Parati, E.A.; Del Giovane, C. Stem cell transplantation for ischemic stroke. Cochrane Database Syst. Rev. 2019, 5, CD007231. [CrossRef]

58. Nguyen, L.T.; Nguyen, A.T.; Vu, C.D.; Ngo, D.V.; Bui, A.V. Outcomes of autologous bone marrow mononuclear cells for cerebral palsy: An open label uncontrolled clinical trial. BMC Pediatr. 2017, 17, 104. [CrossRef]

59. Cox, C.S.; Baumgartner, J.E.; Harting, M.T.; Worth, L.L.; Walker, P.A.; Shah, S.K.; Ewing-Cobbs, L.; Hasan, K.M.; Day, M.C.; Lee, D.; et al. Autologous bone marrow mononuclear cell therapy for severe traumatic brain injury in children. Neurosurgery 2011, 68, 588-600. [CrossRef] [PubMed]

60. Sun, J.M.; Kurtzberg, J. Stem cell therapies in cerebral palsy and autism spectrum disorder. Dev. Med. Child. Neurol. 2021, 63, 503-510. [CrossRef]

61. Romanov, Y.A.; Tarakanov, O.P.; Radaev, S.M.; Dugina, T.N.; Ryaskina, S.S.; Darevskaya, A.N.; Morozova, Y.V.; Khachatryan, W.A.; Lebedev, K.E.; Zotova, N.S.; et al. Human allogeneic AB0/Rh-identical umbilical cord blood cells in the treatment of juvenile patients with cerebral palsy. Cytotherapy 2015, 17, 969-978. [CrossRef]

62. Jiao, Y.; Li, X.Y.; Liu, J. A New Approach to Cerebral Palsy Treatment: Discussion of the Effective Components of Umbilical Cord Blood and its Mechanisms of Action. Cell Transplant. 2019, 28, 497-509. [CrossRef]

63. Phuc, P.V.; Ngoc, V.B.; Lam, D.H.; Tam, N.T.; Viet, P.Q.; Ngoc, P.K. Isolation of three important types of stem cells from the same samples of banked umbilical cord blood. Cell Tissue Bank. 2012, 13, 341-351. [CrossRef] [PubMed]

64. McDonald, C.A.; Fahey, M.C.; Jenkin, G.; Miller, S.L. Umbilical cord blood cells for treatment of cerebral palsy; timing and treatment options. Pediatr. Res. 2018, 83, 333-344. [CrossRef]

65. Novak, I.; Walker, K.; Hunt, R.W.; Wallace, E.M.; Fahey, M.; Badawi, N. Concise Review: Stem Cell Interventions for People With Cerebral Palsy: Systematic Review With Meta-Analysis. Stem Cells Transl. Med. 2016, 5, 1014-1025. [CrossRef] [PubMed] 
66. Rizk, M.; Aziz, J.; Shorr, R.; Allan, D.S. Cell-Based Therapy Using Umbilical Cord Blood for Novel Indications in Regenerative Therapy and Immune Modulation: An Updated Systematic Scoping Review of the Literature. Biol. Blood Marrow Transplant. 2017, 23, 1607-1613. [CrossRef] [PubMed]

67. Forraz, N.; McGuckin, C.P. The umbilical cord: A rich and ethical stem cell source to advance regenerative medicine. Cell Prolif. 2011, 44 (Suppl. 1), 60-69. [CrossRef]

68. Matsumoto, M.M.; Matthews, K.R. A Need for Renewed and Cohesive US Policy on Cord Blood Banking. Stem Cell Rev. Rep. 2015, 11, 789-797. [CrossRef]

69. Han, M.X.; Craig, M.E. Research using autologous cord blood-Time for a policy change. Med. J. Aust. 2013, 199, 288-299. [CrossRef]

70. Van de Ven, C.; Collins, D.; Bradley, M.B.; Morris, E.; Cairo, M.S. The potential of umbilical cord blood multipotent stem cells for nonhematopoietic tissue and cell regeneration. Exp. Hematol. 2007, 35, 1753-1765. [CrossRef] [PubMed]

71. Dominici, M.; Le Blanc, K.; Mueller, I.; Slaper-Cortenbach, I.; Marini, F.; Krause, D.; Deans, R.; Keating, A.; Prockop, D.J.; Horwitz, E. Minimal criteria for defining multipotent mesenchymal stromal cells. The International Society for Cellular Therapy position statement. Cytotherapy 2006, 8, 315-317. [CrossRef]

72. Siniscalco, D.; Sapone, A.; Cirillo, A.; Giordano, C.; Maione, S.; Antonucci, N. Autism spectrum disorders: Is mesenchymal stem cell personalized therapy the future? J. Biomed. Biotechnol. 2012, 2012, 480289. [CrossRef] [PubMed]

73. Pricola, K.L.; Kuhn, N.Z.; Haleem-Smith, H.; Song, Y.; Tuan, R.S. Interleukin-6 maintains bone marrow-derived mesenchymal stem cell stemness by an ERK1/2-dependent mechanism. J. Cell Biochem. 2009, 108, 577-588. [CrossRef] [PubMed]

74. Lv, F.J.; Tuan, R.S.; Cheung, K.M.; Leung, V.Y. Concise review: The surface markers and identity of human mesenchymal stem cells. Stem Cells 2014, 32, 1408-1419. [CrossRef]

75. Drela, K.; Lech, W.; Figiel-Dabrowska, A.; Zychowicz, M.; Mikula, M.; Sarnowska, A.; Domanska-Janik, K. Enhanced neurotherapeutic potential of Wharton's Jelly-derived mesenchymal stem cells in comparison with bone marrow mesenchymal stem cells culture. Cytotherapy 2016, 18, 497-509. [CrossRef]

76. Siniscalco, D.; Giordano, C.; Galderisi, U.; Luongo, L.; Alessio, N.; Di Bernardo, G.; de Novellis, V.; Rossi, F.; Maione, S. Intra-brain microinjection of human mesenchymal stem cells decreases allodynia in neuropathic mice. Cell Mol. Life Sci. 2010, 67, 655-669. [CrossRef] [PubMed]

77. Bianco, P. “Mesenchymal” stem cells. Annu Rev. Cell Dev. Biol. 2014, 30, 677-704. [CrossRef] [PubMed]

78. Obtulowicz, P.; Lech, W.; Strojek, L.; Sarnowska, A.; Domanska-Janik, K. Induction of Endothelial Phenotype From Wharton's Jelly-Derived MSCs and Comparison of Their Vasoprotective and Neuroprotective Potential With Primary WJ-MSCs in CA1 Hippocampal Region Ex Vivo. Cell Transplant. 2016, 25, 715-727. [CrossRef] [PubMed]

79. Singer, N.G.; Caplan, A.I. Mesenchymal stem cells: Mechanisms of inflammation. Annu. Rev. Pathol. 2011, 6, 457-478. [CrossRef] [PubMed]

80. Newman, R.E.; Yoo, D.; LeRoux, M.A.; Danilkovitch-Miagkova, A. Treatment of inflammatory diseases with mesenchymal stem cells. Inflamm. Allergy Drug Targets 2009, 8, 110-123. [CrossRef]

81. Siniscalco, D.; Kannan, S.; Semprún-Hernández, N.; Eshraghi, A.A.; Brigida, A.L.; Antonucci, N. Stem cell therapy in autism: Recent insights. Stem Cells Cloning 2018, 11, 55-67. [CrossRef]

82. Lalu, M.M.; McIntyre, L.; Pugliese, C.; Fergusson, D.; Winston, B.W.; Marshall, J.C.; Granton, J.; Stewart, D.J. Safety of cell therapy with mesenchymal stromal cells (SafeCell): A systematic review and meta-analysis of clinical trials. PLoS ONE 2012, 7, e47559. [CrossRef]

83. Santilli, G.; Lamorte, G.; Carlessi, L.; Ferrari, D.; Rota Nodari, L.; Binda, E.; Delia, D.; Vescovi, A.L.; De Filippis, L. Mild hypoxia enhances proliferation and multipotency of human neural stem cells. PLoS ONE 2010, 5, e8575. [CrossRef] [PubMed]

84. Hsu, Y.C.; Lee, D.C.; Chiu, I.M. Neural stem cells, neural progenitors, and neurotrophic factors. Cell Transplant. 2007, 16, 133-150. [CrossRef]

85. Casarosa, S.; Bozzi, Y.; Conti, L. Neural stem cells: Ready for therapeutic applications? Mol. Cell Ther. 2014, 2, 31. [CrossRef]

86. Chou, C.H.; Fan, H.C.; Hueng, D.Y. Potential of Neural Stem Cell-Based Therapy for Parkinson's Disease. Parkinsons Dis. 2015, 2015, 571475. [CrossRef] [PubMed]

87. Mazzini, L.; Gelati, M.; Profico, D.C.; Sgaravizzi, G.; Projetti Pensi, M.; Muzi, G.; Ricciolini, C.; Rota Nodari, L.; Carletti, S.; Giorgi, C.; et al. Human neural stem cell transplantation in ALS: Initial results from a phase I trial. J. Transl. Med. $2015,13,17$. [CrossRef] [PubMed]

88. Lech, W.; Figiel-Dabrowska, A.; Sarnowska, A.; Drela, K.; Obtulowicz, P.; Noszczyk, B.H.; Buzanska, L.; Domanska-Janik, K. Phenotypic, Functional, and Safety Control at Preimplantation Phase of MSC-Based Therapy. Stem Cells Int. 2016, $2016,2514917$. [CrossRef]

89. Okur, S.Ç.; Erdoğan, S.; Demir, C.S.; Günel, G.; Karaöz, E. The Effect of Umbilical Cord-derived Mesenchymal Stem Cell Transplantation in a Patient with Cerebral Palsy: A Case Report. Int. J. Stem Cells 2018, 11, 141-147. [CrossRef]

90. Ardhanareeswaran, K.; Coppola, G.; Vaccarino, F. The use of stem cells to study autism spectrum disorder. Yale J. Biol. Med. 2015, 88, 5-16.

91. Szabłowska-Gadomska, I.; Bużańska, L.; Małecki, M. Stem cell properties, current legal status and medical application. Postepy Hig. Med. Dosw. 2017, 71, 1216-1230. [CrossRef] 
92. Brigida, A.L.; Siniscalco, D. Induced pluripotent stem cells as a cellular model for studying Down Syndrome. J. Stem Cells Regen. Med. 2016, 12, 54-60. [CrossRef] [PubMed]

93. Augustyniak, J.; Zychowicz, M.; Podobinska, M.; Barta, T.; Buzanska, L. Reprogramming of somatic cells: Possible methods to derive safe, clinical-grade human induced pluripotent stem cells. Acta Neurobiol. Exp. 2014, 74, 373-382.

94. Rao, M.S.; Malik, N. Assessing iPSC reprogramming methods for their suitability in translational medicine. J. Cell Biochem. 2012, 113, 3061-3068. [CrossRef]

95. Jeon, I.; Choi, C.; Lee, N.; Im, W.; Kim, M.; Oh, S.H.; Park, I.H.; Kim, H.S.; Song, J. In Vivo Roles of a Patient-Derived Induced Pluripotent Stem Cell Line (HD72-iPSC) in the YAC128 Model of Huntington's Disease. Int. J. Stem Cells 2014, 7, 43-47. [CrossRef]

96. Nizzardo, M.; Simone, C.; Rizzo, F.; Ruggieri, M.; Salani, S.; Riboldi, G.; Faravelli, I.; Zanetta, C.; Bresolin, N.; Comi, G.P.; et al. Minimally invasive transplantation of iPSC-derived ALDHhiSSCloVLA4+ neural stem cells effectively improves the phenotype of an amyotrophic lateral sclerosis model. Hum. Mol. Genet. 2014, 23, 342-354. [CrossRef]

97. Sun, J.M.; Kurtzberg, J. Cell Therapy for Diverse Central Nervous System Disorders: Inherited Metabolic Diseases and Autism. Pediatr. Res. 2018, 83, 364-371. [CrossRef] [PubMed]

98. Pistollato, F.; Forbes-Hernández, T.Y.; Calderón Iglesias, R.; Ruiz, R.; Elexpuru Zabaleta, M.; Cianciosi, D.; Giampieri, F.; Battino, M. Pharmacological, Non-Pharmacological and Stem Cell Therapies for the Management of Autism Spectrum Disorders: A Focus on Human Studies. Pharmacol. Res. 2020, 152, 104579. [CrossRef]

99. Bradstreet, J.J.; Vogelaar, E.; Thyer, L. Initial Observations of Elevated Alpha-N-Acetylgalactosaminidase Activity Associated with Autism and Observed Reductions from GC Protein-Macrophage Activating Factor Injections. Autism. Insights 2012, 4, 31-38. [CrossRef]

100. Sajdel-Sulkowska, E.M.; Xu, M.; McGinnis, W.; Koibuchi, N. Brain Region-Specific Changes in Oxidative Stress and Neurotrophin Levels in Autism Spectrum Disorders (ASD). Cerebellum 2011, 10, 43-48. [CrossRef] [PubMed]

101. Fatemi, S.H.; Aldinger, K.A.; Ashwood, P.; Bauman, M.L.; Blaha, C.D.; Blatt, G.J.; Chauhan, A.; Chauhan, V.; Dager, S.R.; Dickson, P.E. Consensus Paper: Pathological Role of the Cerebellum in Autism. Cerebellum 2012, 11, 777-807. [CrossRef] [PubMed]

102. Weick, J.P.; Liu, Y.; Zhang, S.-C. Human Embryonic Stem Cell-Derived Neurons Adopt and Regulate the Activity of an Established Neural Network. Proc. Natl. Acad. Sci. USA 2011, 108, 20189-20194. [CrossRef]

103. Höing, S.; Rudhard, Y.; Reinhardt, P.; Glatza, M.; Stehling, M.; Wu, G.; Peiker, C.; Böcker, A.; Parga, J.A.; Bunk, E.; et al. Discovery of Inhibitors of Microglial Neurotoxicity Acting Through Multiple Mechanisms Using a Stem-Cell-Based Phenotypic Assay. Cell Stem Cell 2012, 11, 620-632. [CrossRef]

104. Kaya, M.; Karasalihoğlu, S.; Üstün, F.; Gültekin, A.; Çermik, T.F.; Fazlığlu, Y.; Türe, M.; Yiğitbaşı, Ö.N.; Berkarda, Ş. The Relationship between 99mTc-HMPAO Brain SPECT and the Scores of Real Life Rating Scale in Autistic Children. Brain Dev. 2002, 24, 77-81. [CrossRef]

105. Calió, M.L.; Marinho, D.S.; Ko, G.M.; Ribeiro, R.R.; Carbonel, A.F.; Oyama, L.M.; Ormanji, M.; Guirao, T.P.; Calió, P.L.; Reis, L.A.; et al. Transplantation of Bone Marrow Mesenchymal Stem Cells Decreases Oxidative Stress, Apoptosis, and Hippocampal Damage in Brain of a Spontaneous Stroke Model. Free Radic. Biol. Med. 2014, 70, 141-154. [CrossRef] [PubMed]

106. Wada, N.; Gronthos, S.; Bartold, P.M. Immunomodulatory Effects of Stem Cells. Periodontology 2000 2013, 63, 198-216. [CrossRef] [PubMed]

107. Siniscalco, D.; Bradstreet, J.J.; Sych, N.; Antonucci, N. Perspectives on the Use of Stem Cells for Autism Treatment. Stem Cells Int. 2013, 2013, 1-7. [CrossRef]

108. Nguyen Thanh, L.; Nguyen, H.; Ngo, M.D.; Bui, V.A.; Dam, P.T.M.; Bui, H.T.P.; Ngo, D.V.; Tran, K.T.; Dang, T.T.T.; Duong, B.D.; et al. Outcomes of Bone Marrow Mononuclear Cell Transplantation Combined with Interventional Education for Autism Spectrum Disorder. Stem Cells Transl. Med. 2021, 10, 14-26. [CrossRef] [PubMed]

109. Sharma, A.; Gokulchandran, N.; Sane, H.; Nagrajan, A.; Paranjape, A.; Kulkarni, P.; Shetty, A.; Mishra, P.; Kali, M.; Biju, H.; et al. Autologous Bone Marrow Mononuclear Cell Therapy for Autism: An Open Label Proof of Concept Study. Stem Cells Int. 2013, 2013, 1-13. [CrossRef] [PubMed]

110. Dawson, G.; Sun, J.M.; Davlantis, K.S.; Murias, M.; Franz, L.; Troy, J.; Simmons, R.; Sabatos-DeVito, M.; Durham, R.; Kurtzberg, J. Autologous Cord Blood Infusions Are Safe and Feasible in Young Children with Autism Spectrum Disorder: Results of a Single-Center Phase I Open-Label Trial: Autologous Umbilical Cord Blood in Autism Spectrum Disorder. Stem Cells Transl. Med. 2017, 6, 1332-1339. [CrossRef]

111. Dawson, G.; Sun, J.M.; Baker, J.; Carpenter, K.; Compton, S.; Deaver, M.; Franz, L.; Heilbron, N.; Herold, B.; Horrigan, J.; et al. A Phase II Randomized Clinical Trial of the Safety and Efficacy of Intravenous Umbilical Cord Blood Infusion for Treatment of Children with Autism Spectrum Disorder. J. Pediatr. 2020, 222, 164-173.e5. [CrossRef]

112. Chez, M.; Lepage, C.; Parise, C.; Dang-Chu, A.; Hankins, A.; Carroll, M. Safety and Observations from a Placebo-Controlled, Crossover Study to Assess Use of Autologous Umbilical Cord Blood Stem Cells to Improve Symptoms in Children with Autism. Stem Cells Transl. Med. 2018, 7, 333-341. [CrossRef]

113. Huang, H.; Young, W.; Chen, L.; Feng, S.; Zoubi, Z.M.A.; Sharma, H.S.; Saberi, H.; Moviglia, G.A.; He, X.; Muresanu, D.F.; et al. Clinical Cell Therapy Guidelines for Neurorestoration (IANR/CANR 2017). Cell Transp. 2018, 27, 310-324. [CrossRef] [PubMed]

114. Smithers-Sheedy, H.; Badawi, N.; Blair, E.; Cans, C.; Himmelmann, K.; Krägeloh-Mann, I.; McIntyre, S.; Slee, J.; Uldall, P.; Watson, L.; et al. What constitutes cerebral palsy in the twenty-first century? Dev. Med. Child. Neurol. 2014, 56, 323-328. [CrossRef] 
115. Chen, G.; Wang, Y.; Xu, Z.; Fang, F.; Xu, R.; Wang, Y.; Hu, X.; Fan, L.; Liu, H. Neural stem cell-like cells derived from autologous bone mesenchymal stem cells for the treatment of patients with cerebral palsy. J. Transl Med. 2013, 11, 21. [CrossRef] [PubMed]

116. Eggenberger, S.; Boucard, C.; Schoeberlein, A.; Guzman, R.; Limacher, A.; Surbek, D.; Mueller, M. Stem cell treatment and cerebral palsy: Systemic review and meta-analysis. World J. Stem Cells 2019, 11, 891-903. [CrossRef] [PubMed]

117. Luan, Z.; Liu, W.; Qu, S.; Du, K.; He, S.; Wang, Z.; Yang, Y.; Wang, C.; Gong, X. Effects of neural progenitor cell transplantation in children with severe cerebral palsy. Cell Transplant. 2012, 21 (Suppl. 1), S91-S98. [CrossRef] [PubMed]

118. Abi Chahine, N.H.; Wehbe, T.W.; Hilal, R.A.; Zoghbi, V.V.; Melki, A.E.; Habib, E.B. Treatment of Cerebral Palsy with Stem Cells: A Report of 17 Cases. Int. J. Stem Cells 2016, 9, 90-95. [CrossRef]

119. Alessandrini, M.; Preynat-Seauve, O.; De Bruin, K.; Pepper, M.S. Stem cell therapy for neurological disorders. S. Afr. Med. J. 2019, 109, 70-77. [CrossRef]

120. Paulson, A.; Vargus-Adams, J. Overview of Four Functional Classification Systems Commonly Used in Cerebral Palsy. Children 2017, 4, 30. [CrossRef]

121. Palisano, R.; Rosenbaum, P.; Walter, S.; Russell, D.; Wood, E.; Galuppi, B. Development and reliability of a system to classify gross motor function in children with cerebral palsy. Dev. Med. Child. Neurol. 1997, 39, 214-223. [CrossRef]

122. Alotaibi, M.; Long, T.; Kennedy, E.; Bavishi, S. The efficacy of GMFM-88 and GMFM-66 to detect changes in gross motor function in children with cerebral palsy (CP): A literature review. Disabil. Rehabil. 2014, 36, 617-627. [CrossRef] [PubMed]

123. Goldman, S.A.; Kuypers, N.J. How to make an oligodendrocyte. Development 2015, 142, 3983-3995. [CrossRef]

124. Sharma, A.; Sane, H.; Gokulchandran, N.; Kulkarni, P.; Gandhi, S.; Sundaram, J.; Paranjape, A.; Shetty, A.; Bhagwanani, K.; Biju, H.; et al. A clinical study of autologous bone marrow mononuclear cells for cerebral palsy patients: A new frontier. Stem Cells Int. 2015, 2015, 905874. [CrossRef]

125. Nguyen, T.L.; Nguyen, H.P.; Nguyen, T.K. The effects of bone marrow mononuclear cell transplantation on the quality of life of children with cerebral palsy. Health Qual. Life Outcomes 2018, 16, 164. [CrossRef] [PubMed]

126. Chen, L.; Huang, H.; Xi, H.; Xie, Z.; Liu, R.; Jiang, Z.; Zhang, F.; Liu, Y.; Chen, D.; Wang, Q.; et al. Intracranial transplant of olfactory ensheathing cells in children and adolescents with cerebral palsy: A randomized controlled clinical trial. Cell Transplant. 2010, 19, 185-191. [CrossRef] [PubMed]

127. Ruff, C.A.; Faulkner, S.D.; Fehlings, M.G. The potential for stem cell therapies to have an impact on cerebral palsy: Opportunities and limitations. Dev. Med. Child. Neurol. 2013, 55, 689-697. [CrossRef] [PubMed]

128. He, S.; Luan, Z.; Qu, S.; Qiu, X.; Xin, D.; Jia, W.; Shen, Y.; Yu, Z.; Xu, T. Ultrasound guided neural stem cell transplantation through the lateral ventricle for treatment of cerebral palsy in children. Neural. Regen Res. 2012, 7, 2529-2535. [CrossRef] [PubMed]

129. Sherman, L.S.; Romagano, M.P.; Williams, S.F.; Rameshwar, P. Mesenchymal stem cell therapies in brain disease. Semin. Cell Dev. Biol. 2019, 95, 111-119. [CrossRef] [PubMed]

130. Kim, H.; Na, D.L.; Lee, N.K.; Kim, A.R.; Lee, S.; Jang, H. Intrathecal Injection in A Rat Model: A Potential Route to Deliver Human Wharton's Jelly-Derived Mesenchymal Stem Cells into the Brain. Int. J. Mol. Sci. 2020, 21, 1272. [CrossRef]

131. Galeano, C.; Qiu, Z.; Mishra, A.; Farnsworth, S.L.; Hemmi, J.J.; Moreira, A.; Edenhoffer, P.; Hornsby, P.J. The Route by Which Intranasally Delivered Stem Cells Enter the Central Nervous System. Cell Transplant. 2018, 27, 501-514. [CrossRef]

132. Lochhead, J.J.; Thorne, R.G. Intranasal delivery of biologics to the central nervous system. Adv. Drug Deliv. Rev. 2012, 64, 614-628. [CrossRef]

133. Wang, X.; Cheng, H.; Hua, R.; Yang, J.; Dai, G.; Zhang, Z.; Wang, R.; Qin, C.; An, Y. Effects of bone marrow mesenchymal stromal cells on gross motor function measure scores of children with cerebral palsy: A preliminary clinical study. Cytotherapy 2013, 15, 1549-1562. [CrossRef]

134. Mancías-Guerra, C.; Marroquín-Escamilla, A.R.; González-Llano, O.; Villarreal-Martínez, L.; Jaime-Pérez, J.C.; GarcíaRodríguez, F.; Valdés-Burnes, S.L.; Rodríguez-Romo, L.N.; Barrera-Morales, D.C.; Sánchez-Hernández, J.J.; et al. Safety and tolerability of intrathecal delivery of autologous bone marrow nucleated cells in children with cerebral palsy: An open-label phase I trial. Cytotherapy 2014, 16, 810-820. [CrossRef] [PubMed]

135. Zali, A.; Arab, L.; Ashrafi, F.; Mardpour, S.; Niknejhadi, M.; Hedayati-Asl, A.A.; Halimi-Asl, A.; Ommi, D.; Hosseini, S.E.; Baharvand, H.; et al. Intrathecal injection of CD133-positive enriched bone marrow progenitor cells in children with cerebral palsy: Feasibility and safety. Cytotherapy 2015, 17, 232-241. [CrossRef] [PubMed]

136. DaCosta, J.C.; Portuguez, M.W.; Marinowic, D.R.; Schilling, L.P.; Torres, C.M.; DaCosta, D.I.; Carrion, M.; Raupp, E.F.; Machado, D.C.; Soder, R.B.; et al. Safety and seizure control in patients with mesial temporal lobe epilepsy treated with regional superselective intra-arterial injection of autologous bone marrow mononuclear cells. J. Tissue Eng. Regen. Med. 2018, 12, e648-e656. [CrossRef] [PubMed]

137. Milczarek, O.; Jarocha, D.; Starowicz-Filip, A.; Kwiatkowski, S.; Badyra, B.; Majka, M. Multiple Autologous Bone Marrow-Derived CD271 ${ }^{+}$Mesenchymal Stem Cell Transplantation Overcomes Drug-Resistant Epilepsy in Children. Stem Cells Transl. Med. 2018, 7, 20-33. [CrossRef] [PubMed] 